\title{
Using a Multi-Proxy Approach to Detect and Date a Buried part of the Hellenistic City Wall of Ainos (NW Turkey)
}

\author{
Martin Seeliger ${ }^{1, *}$, Anna Pint ${ }^{2}$, Peter Frenzel ${ }^{3}$, Paula K. Weisenseel ${ }^{3}$, Ercan Erkul ${ }^{4}$, \\ Dennis Wilken ${ }^{4}$, Tina Wunderlich ${ }^{4}$, Sait Başaran ${ }^{5}$, Heike Bücherl ${ }^{6}$, Marina Herbrecht ${ }^{2}$, \\ Wolfgang Rabbel ${ }^{4}$, Thomas Schmidts ${ }^{7}$, Nina Szemkus ${ }^{2}$ and Helmut Brückner ${ }^{2}$ \\ 1 Department of Physical Geography, Faculty of Geosciences, Goethe University Frankfurt, Altenhöferallee 1, \\ 60438 Frankfurt, Germany \\ 2 Institute of Geography, University of Cologne, Albertus-Magnus-Platz, 50923 Köln, Germany; \\ annapint@web.de (A.P.); marina.herbrecht@uni-koeln.de (M.H.); ninaszemkus@yahoo.de (N.S); \\ h.brueckner@uni-koeln.de (H.B.) \\ 3 Institute of Earth Sciences, Friedrich Schiller University Jena, Burgweg 11, 07749 Jena, Germany; \\ peter.frenzel@uni-jena.de (P.F.); paula.katharina.weisenseel@uni-jena.de (P.K.W.) \\ 4 Institute of Geosciences, Department of Geophysics, Kiel University, Otto-Hahn-Platz 1, 24118 Kiel, \\ Germany; ercan.erkul@ifg.uni-kiel.de (E.E.); dennis.wilken@ifg.uni-kiel.de (D.W.); \\ tina.wunderlich@ifg.uni-kiel.de (T.W.); wolfgang.rabbel@ifg.uni-kiel.de (W.R.) \\ 5 Edebiyat Fakültesi, İstanbul Üniversitesi, Beyazıt, 34452 Fatih/Istanbul, Turkey; sait.basaran@gmail.com \\ 6 Department for Historical Building Research and Preservation, TU Berlin, Straße des 17. Juni 152, \\ 10623 Berlin, Germany; heike.buecherl@tu-berlin.de \\ 7 Museum of Ancient Seafaring, Neutorstraße 2b, 55116 Mainz, Germany; schmidts@rgzm.de \\ * Correspondence: seeliger@em.uni-frankfurt.de; Tel.: +49-69-798-40231
}

Received: 14 August 2018; Accepted: 6 September 2018; Published: 20 September 2018

\begin{abstract}
Throughout mankind's history, the need to secure and protect the home settlement was an essential one. This holds especially true for the city of Ainos (modern Enez) in Turkish Thrace. Due to its continuous settlement history since the 7th/6th century BC, several different types of city walls were built-sometimes even on top of each other-several of which have been preserved over time. To decipher the construction style, the course and the age of a buried city wall segment in the southern part of the former city, a geoscientific multi-proxy approach including magnetic gradiometer (MG) and electrical resistivity tomography (ERT) measurements in combination with granulometrical, sedimentological and microfaunistical investigations on sediment cores was applied. We were able to (1) present reasonable arguments for its Hellenistic age; (2) reveal the course of this wall segment and extrapolate it further north into a less studied area; and (3) demonstrate that in this near-coastal area, the former swampy terrain had been consolidated for constructing the wall. Our multi-proxy approach serves as a valuable example for investigating buried structures in archaeological contexts, avoiding a less-economical, time-consuming, or even forbidden excavation.
\end{abstract}

Keywords: foraminifera; micropalaeontology; coastal geomorphology; geophysical prospections; magnetic gradiometry; electrical resistivity tomography; aegean

\section{Introduction}

Several ancient civilisations possessed high-level skills in partially unique methods of construction. Some of these technical abilities have been lost over time, and it is difficult to reproduce them even with modern techniques. This is also true for engineering activities relating to the construction of city walls. Fortifications were an essential feature of settlements since the beginnings in the Neolithic era. 
They were primarily erected to provide security for the settlers and to give shelter in troubled times for the people living nearby. Additionally, they were an object of the city's representation, its power, and wealth. City gates, especially, were often decorated by rich ornaments to impress incoming guests. Fortifications counted among the biggest and most expensive building projects of communities. Due to their massive construction, ancient city walls, or at least parts of them, have survived at many sites until today. As important hints with regard to the historical and cultural evolution of civilizations, they are still the focus of current research [1-4].

Chronology presents a huge problem when studying the history, construction, and utilisation of ancient city walls-especially of buried or partly ruined ones. Common dating methods are based on the investigation of their dimensions, especially width and course, gateways and towers, masonry style, as well as integrated pottery, inscriptions and spolia used [2].

By applying a multi-proxy approach, this paper presents the results of a geoarchaeological, geophysical, microfaunal, and geochronological research on the buried part of the city wall in the south-western part of Ainos in order to (1) verify its construction style and age; (2) prove its further extension in less-studied and difficult-to-access areas; and (3) decipher the general landscape evolution in this part of the city during the past 5000 years. This approach has been widely adopted in Mediterranean coastal studies e.g., [5-21] to investigate lateral and vertical changes in the sediment stratigraphy and to probe the evolution of the landscape, notably coastline migration. Furthermore, Elaia [22], as well as Tayma [23], can act as valuable examples for investigating buried wall structures using a multi-proxy approach.

\section{Study Area}

\subsection{Geographical Setting}

Enez (ancient Ainos) is located in the remote westernmost area of Turkish Thrace, in the direct vicinity of the river mouth of the Hebros that debouches into the Aegean Sea by creating an extensive deltaic floodplain of $180 \mathrm{~km}^{2}$ between the Greek city Alexandroupoli and the Turkish city Enez. The terminal $215 \mathrm{~km}$ of its modern river course forms the border between Greece and Turkey (Figure 1) [24,25].

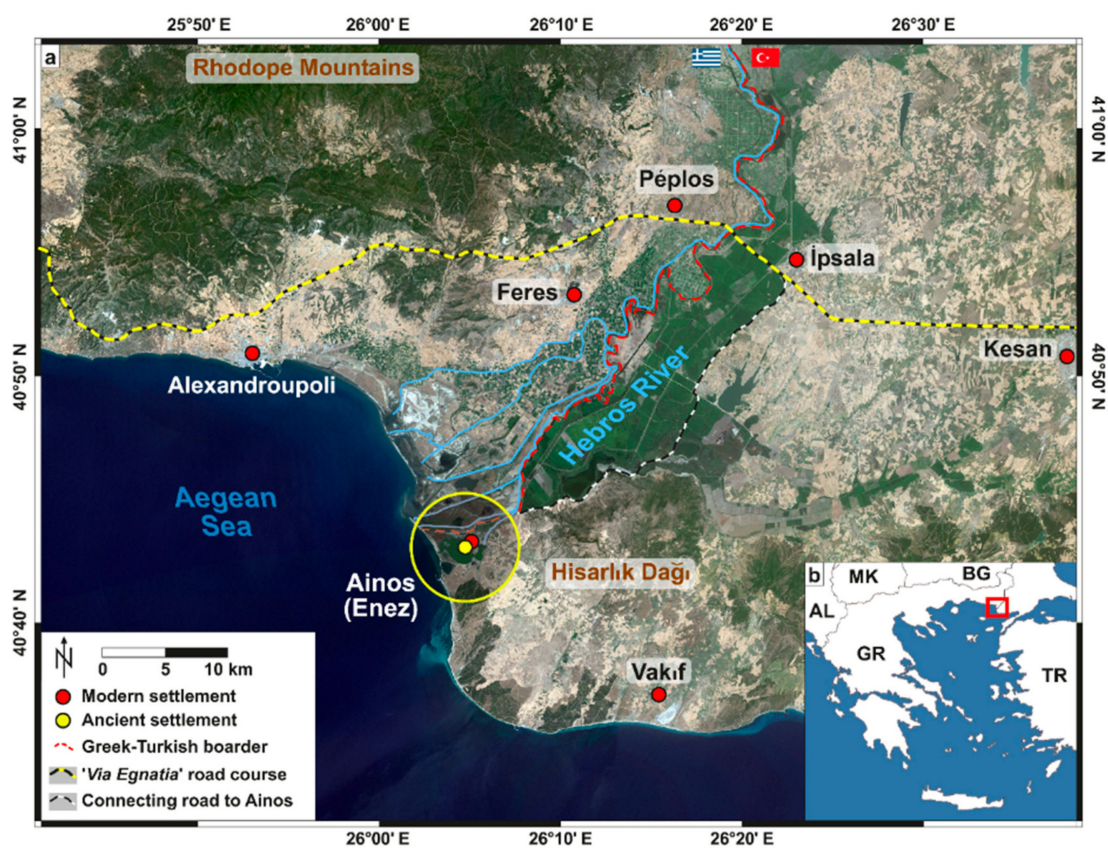

Figure 1. Research area at the border between Turkey and Greece. (a) Overview map (based on Landsat 8; acquired 13 June 2014; composition of bands 4,3,1) with locations mentioned in the text; (b) position of 1a on a general map of the Aegean Sea. 
Enez, as well as its predecessor settlement Ainos, is situated on an up to $25 \mathrm{~m}$ high limestone promontory, which is surrounded by the Taşaltı-Gölü lagoon to the south, the Dalyan-Gölü lagoon to the west, and the southernmost branch of the Hebros to its north. In contrast, the eastern part of the castle hill is nowadays the main gateway to the modern city. At a distance, the Hisarlık Dağ highlands, composed of late Tertiary volcanic rocks, rise up to $385 \mathrm{~m}$ (Figure 1). Nowadays, the Dalyan-Gölü is separated from the Aegean Sea by a complex barrier beach system; each year in autumn, it is opened for fishing purposes (Figure 2) [24,26,27].

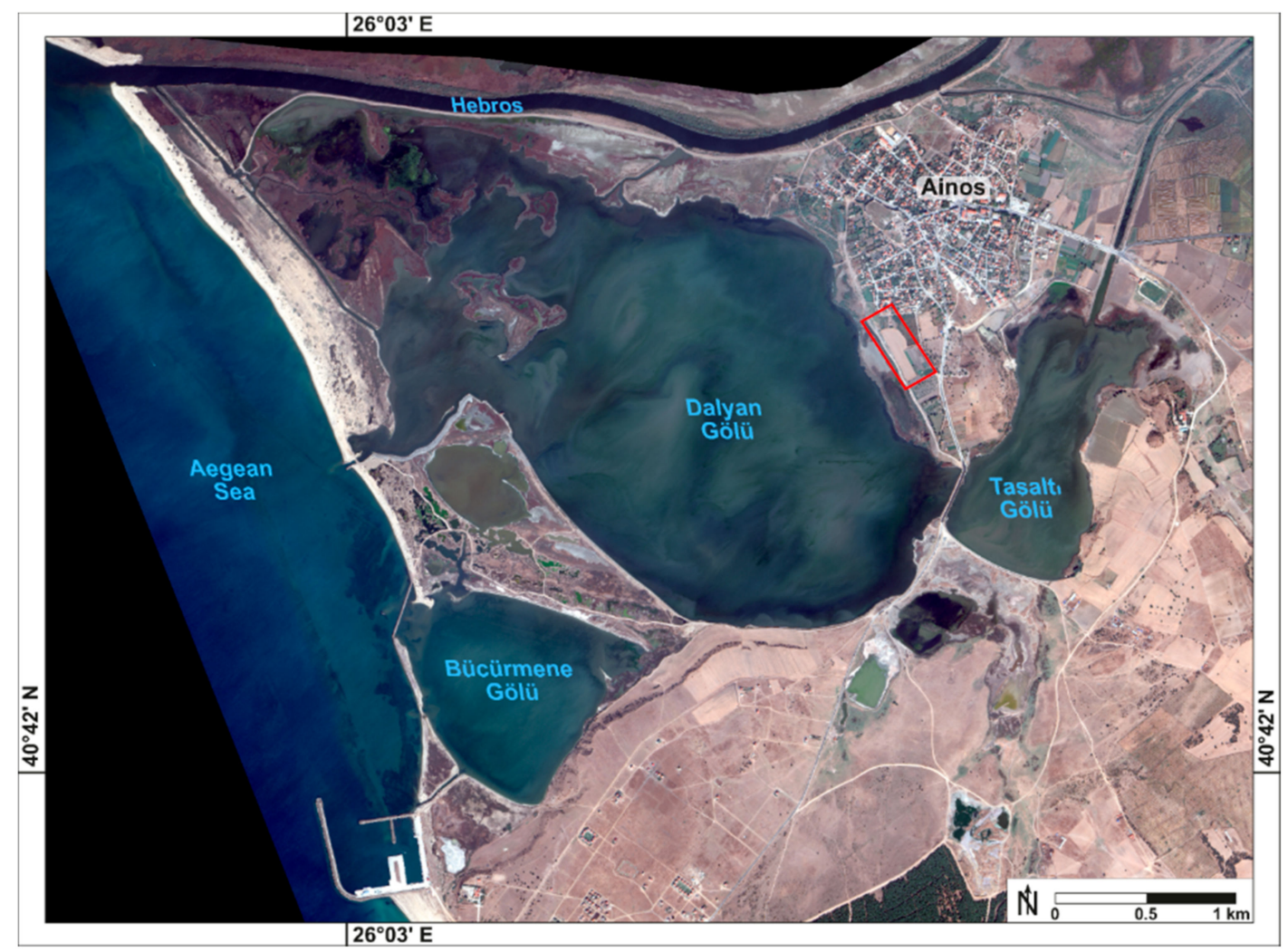

Figure 2. Ainos and its environs. The red rectangle marks the area of the investigated city wall (based on Worldview2; acquired 04 October 2012; composition of bands 1, 3, 6).

The environs of Enez are characterised by swampy marshes and small coastal lakes; the ephemeral ones receive their water supply by rainfall and the channel flow of the Hebros [26,28-31].

The region lies in close vicinity to the NAFZ (North Anatolian Fault Zone) which makes it vulnerable to earthquakes, and potentially also to tsunami impact. The ongoing uplift during the late Quaternary is evident from marine terraces, backed with the finds of marine fossils at the northern foot of the Hisarlık Dağı highlands [32]. As in the cases for many river valleys bordering the Aegean Sea, the postglacial sea-level rise created a marine embayment that reached far inland and in case of the Hebros valley region nearly as far as the modern town of İpsala, i.e., 26 km inland (Figure 1) [5,6,24].

\subsection{Historical Background}

Throughout history, Ainos has had a threefold unique location with direct access to the open Aegean Sea, to its hinterland via the Hebros, as well as a widely ramified road system. Therefore, the city acted as a hub for the diverse traffic activities between the Balkans, Anatolia, the Black Sea region, and the Aegean Sea [24,26,27].

Due to its favourable location, the Ainos region shows a settlement history of more than 8000 years. Neolithic finds dated to 6500 BC attest the first settling of the region around a spring called Hoca Çeşme, circa $5 \mathrm{~km}$ east of Ainos [27]. During the peak time of Ainos between the 7th/6th century BC and the 
Byzantine period, its fate was very strongly connected with its function as a harbour city at the river mouth of the Hebros, a river that was navigable upstream far inland contrary to most other Eastern Mediterranean ones.

Ainos was founded as a Greek colony. Homer's Iliad (4.520) hints towards the importance of the city during the 7th century $\mathrm{BC}$, which is testified by imported pottery showing the economic wealth of the settlement already from Archaic times onwards [33,34].

As a member of the Delian league (5th/4th century BC), Ainos was quite often mentioned in literary sources. The amount of paid tributes to the league, extensive coinage, and the production and export of wine from the late 5th century BC onwards is good evidence for the importance of the city [35-38]. In summary, Ainos was counted among the wealthiest cities of this period in the Aegean region $[39,40]$.

Judging from the reduced coinage in Hellenistic times when the city was temporarily part of the Pergamenian Kingdom the importance of Ainos seems to have declined during that period. The same holds true for the entire Roman period. The fact that Ainos was not directly situated at the Via Egnatia partly accounts for this deterioration (Figure 1) [38].

Nevertheless, archaeological evidence does not show an entire decline in wealth. A well-equipped residential building with mosaics, imported pottery and, coin finds shows a modest wealth during the Roman Imperial period [26,41]. Additionally, shipowners (naukleroi) are mentioned in an inscription of Roman age. It is the only one in Roman Thrace that mentions this occupational title and backs Ainos' role as a harbour city.

The city certainly boomed during Late Antiquity (4th-6th century AD), as it was chosen as a diocesan town [42]. Additionally, Procopius (Buildings 4, 2-6, 11,) [43] mentions enormous building activities in Ainos during the reign of Emperor Justinian (AD 527-565).

In Byzantine times, Ainos still acted as a commercial hub. Especially late Byzantine sources convey commercial activities through the Hebros [44]. For this period, Ainos was characterised as a middle-sized harbour city comparable to Smyrna [45]. The Hebros was navigable for larger ships up to Hadrianopolis (modern Edirne in Turkey) and by smaller ones even up to Philippopolis (modern Plovdiv in Bulgaria). In the 15th century AD, shipyards were mentioned for Ainos, and trade connections existed, e.g., to the Marmara Sea and to Crete [44,46]. Additionally, several remains of Byzantine fortifications and churches show the wealth and the importance of the city in those days $[47,48]$.

\section{Material and Methods}

Because an archaeological excavation would have been less-economical conductable in the enlarged area of the buried city wall, lateral and vertical changes of the archaeological and sedimentary stratigraphy were studied by combining areal and profile data from magnetic gradiometry (MG) and electrical resistivity tomography (ERT) with point data from sediment cores.

\subsection{Geoarchaeological and Geophysical Fieldwork}

Corings down to a maximal depth of $8 \mathrm{~m}$ b.s. (m below the surface) with an Atlas Copco Cobra TT vibracorer were performed using open steel auger heads (diameters: $7.5 \mathrm{~cm}, 6 \mathrm{~cm}$, and $5 \mathrm{~cm}$ ). On-site sediments were described according to grain size, colour (Munsell Soil Color Charts), as well as carbonate content; bulk samples for laboratory analyses were taken from the open sediment cores. Due to the compact character of the wall remains, closed steel auger heads with opaque $1 \mathrm{~m}$ long PVC tube liners were not usable in this context. Thus, OSL (optically stimulated luminescence) dating of the sediments below the walls was not possible [22].

The MG survey was performed using an array of six fluxgate gradiometers with an internal vertical sensor distance of $0.65 \mathrm{~m}$, a horizontal sensor spacing of $0.5 \mathrm{~m}$, and a sampling frequency of $20 \mathrm{~Hz}$. Accurate positioning was achieved by RTK (Real Time Kinematic) DGPS (Leica SR530; Leica Geosystems AG, Herrbrugg, Switzerland). The arithmetic mean was subtracted from the data of 
each profile in order to eliminate the constant portion of the magnetic field caused by instruments (cables, GPS, data logger) installed on the instrument vehicle. The resulting values were binned inline and interpolated cross-line between neighbouring profiles to form a data grid, which was plotted on a grey-scale map for interpretation.

Due to different stages of crop growth, not all areas where the city wall was expected to be were accessible during the gradiometer campaign. Thus, three ERT profiles were performed in order to estimate the conductivity pattern of the wall on a part of the wall visible in magnetics and to detect it in the areas not investigated by magnetics. Electrode distance was $1 \mathrm{~m}$. All profiles were measured in Wenner-alpha, Wenner-beta, and Dipole-Dipole configuration. The measured data were pre-processed by deleting negative apparent resistivity values and those with a standard deviation larger than $10 \%$. For a 2D-tomographic inversion of the apparent resistivity pseudo-sections, the program Res2dInv [49] was applied, which takes into account the topography and global coordinates of each electrode. Profile E6 was inverted using data of all configurations, resulting in an RMS error of $13 \%$, profiles E7 and E8 were inverted using the Wenner-alpha configuration, resulting in an RMS error of $1.4 \%$ and $2 \%$.

\subsection{Local Coordinate System, Sea Level and DGPS Measurements}

The position and elevation of each coring were levelled by using DGPS (Topcon HIPER Pro), with a horizontal and vertical resolution of less than $2 \mathrm{~cm}$. The local coordinate system (LCS) applied in Ainos and used for geophysics and coring is based on UTM (zone 35N) using WGS84. By applying the geoid model EGG97, ellipsoid heights were transformed to orthometric ones. The altitude correction of the reference system is proofed according to the ITRF08 standard by processing the data with the web service of the "Geodetic Survey Division, Canada Centre for Remote Sensing, Natural Resources Canada". Own sea-level measurements using DGPS during the field campaigns 2013-2015 showed the correctness of the LCS regarding "real" sea-level heights. Furthermore, those DGPS measurements revealed a micro-tidal regime-not uncommon for the Aegean Sea [28,30,31]. All elevations are stated in $\mathrm{m}$ b.s. (metre below the surface), $\mathrm{m}$ a.s.l. (metre above the present sea level) and $\mathrm{m}$ b.s.l. (metre below the present sea level).

\subsection{Sedimentology and Geochemistry}

Multi-proxy analyses were conducted in the laboratory to augment on-site facies interpretation [30,50-52]. Samples were air-dried, ground with mortar and pestle, and sieved to separate the $\leq 2 \mathrm{~mm}$ grain-size fraction for further analyses.

For the calculation of grain-size parameters, the organic content was decomposed using $15 \%$ hydrogen peroxide $\left(\mathrm{H}_{2} \mathrm{O}_{2}\right)$, sodium pyrophosphate $\left(\mathrm{Na}_{4} \mathrm{P}_{2} \mathrm{O}_{7}\right.$; concentration: $\left.47 \mathrm{~g} / \mathrm{l}\right)$ was taken as a dispersant, followed by laser-based grain-size analysis (Beckman Coulter LS13320). Finally, the grain-size statistics according to [52], were calculated using the GRADISTAT software [53].

LOI (loss on ignition) was performed by oven drying (at $105^{\circ} \mathrm{C}$ for $12 \mathrm{~h}$ ) and combusting in a furnace at $550{ }^{\circ} \mathrm{C}$ for $4 \mathrm{~h}$. Two chemical processes may cause substantial uncertainties dealing with LOI, which are discussed widely, among others by [54] and [55]: the possible loss of structural water out of clay minerals [56], and the potential loss of carbon dioxide from carbonates consisting of inorganic material [57]. These two processes result in a weight reduction not caused by loss of organic substance. This should be kept in mind when interpreting this proxy.

Up to 30 elements were determined by using a portable XRF spectrometer (Niton X13t 900 GOLDD; Analyticon Instruments $\mathrm{GmbH}$, Rosbach vor der Höhe, Germany) [58,59]. To ensure comparability within all XRF analyses and to reduce grain-size dependence, each sample was ground to powder in a ball triturator (Retsch PM 400; Retsch GmbH, Haan, Germany) and afterwards pressed to pills before being measured. 


\subsection{Micropalaeontology}

Additionally, the same samples investigated by sedimentological and geochemical means, were checked for their benthic foraminifera content. Therefore, the samples were prepared by wet-sieving of $1 \mathrm{~cm}^{3}$ through a $100 \mu \mathrm{m}$ mesh. Subsequently, at least 300 tests from appropriate splits of the residues of each sample were picked under a stereoscopic microscope. If less than 300 specimens were present, all tests were picked. The species were identified according to $[60,61]$.

\subsection{Chronology}

${ }^{14} \mathrm{C}$-AMS dating was carried out at the ${ }^{14} \mathrm{Chrono}$ Centre for Climate, the Environment, and Chronology, Queen's University Belfast, UK (lab code: UBA). Depending on the $\delta^{13} \mathrm{C}$-value, each sample was calibrated using either the IntCal13 or the MARINE13 calibration curve of the recent Calib 7.1 (http:/ / calib.org/calib) software [62] with a marine reservoir effect of $390 \pm 85$ years and a $\Delta R$ of $35 \pm 70$ years. [63] use shells of known age sampled in the Dardanelle Strait and stored in the Muséum National d'Histoire Naturelle, Paris to calculate the local marine reservoir age and its $\Delta \mathrm{R}$. Finally, as the spatio-temporal variation of the marine reservoir effect for the Aegean Sea-as well as worldwide-is still not completely understood, the ${ }^{14} \mathrm{C}$-ages of marine carbonates should be interpreted carefully. All ages are presented in calendar years $\mathrm{BC} / \mathrm{AD}$

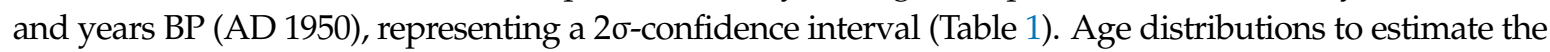
onset of the anthropogenic impact in cores Ain 35, 36, 53, and 58 were calculated using the OxCal 4.2.3 (https://c14.arch.ox.ac.uk/oxcal) calibration software [64].

\section{Results}

\subsection{Results of the Magnetic Survey}

The city wall was investigated by MG on a length of circa $300 \mathrm{~m}$ (Figure 3b). Its track is characterised by a zig-zag design. The shape of the wall comprises several linear parts, named curtains and jutties, that are addressed as towers (Figure 3c). Curtains 1 and 3 are oriented north-south, while curtains 2 and 4 are tending northwest-southeast. Tower $\mathrm{A}$ is detected at the edge of curtains 1 and 2 at the seaward side of the wall. A similar one (tower B) can be assumed at the edge of curtains 3 and 4 where- due to the nearby modern road-no magnetic measurement was possible. The distance between the two towers is circa $100 \mathrm{~m}$. The northernmost curtain 1 is at least $45 \mathrm{~m}$ long; it could not be prospected further northwards due to dense vegetation. Curtain 2 is $48 \mathrm{~m}$ long, while curtain 3 shows an overall length of $60 \mathrm{~m}$ (measured inside from edge to edge). The southernmost curtain 4 is at least $62 \mathrm{~m}$ long, while its southern extension is again unknown due to dense vegetation. The width of the wall anomaly varies between $5.9 \mathrm{~m}$ and $7.4 \mathrm{~m}$. Therefore, the former wall should have been narrower than $5.9 \mathrm{~m}$. According to the results of the MG measurements, towers A and B covered an area of circa $80 \mathrm{~m}^{2}$ each. 


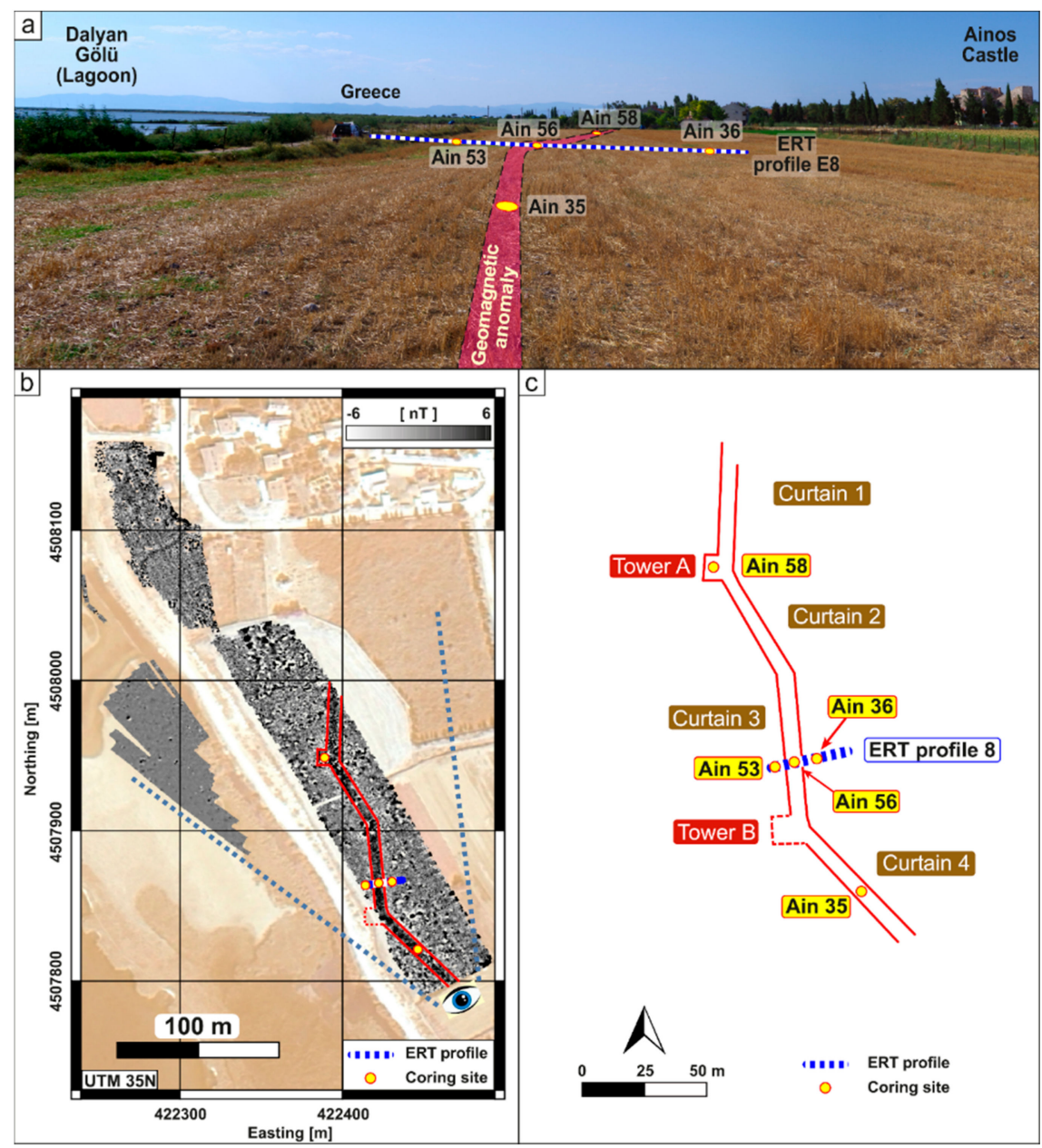

Figure 3. The area of interest (for location see Figure 2). (a) Panoramic view of the research area facing northwest (taken on 01 September 2015 by M.S.; the eye in Figure $3 b$ represents the camera position). It shows the prospected wall course, corings Ain 35, 36, 53, 56, and 58, and ERT (Earth Resistivity Tomography) profile 8; (b) Results of the MG (Magnetic Gradiometer) survey added by the locations of the corings (left); (c) Schematic overview presenting the prospected wall course, as well as the locations of the corings and ERT profile E8 (right).

\subsection{Results of the ERT Profiles}

As it is not possible to estimate the vertical extension of the anomalies visible from the MG measurements, three ERT profiles (E6, E7, and E8) were measured to detect the dimensions and the course of the former city wall northwards (Figure 4), where it was inaccessible by MG measurements.

Profile E8 (length: $60 \mathrm{~m}$, max. depth of penetration: circa $10 \mathrm{~m}$ b.s.) includes the coring sites of Ain 53,56 , and 36 , and is therefore placed in an area where additionally MG measurements were conducted.

The profile is subdivided into two sections. While low values of resistivity $(<50 \Omega \mathrm{m})$ occur between the final depth and circa $2.5 \mathrm{~m}$ b.s., high resistivity $(>50 \Omega \mathrm{m})$ becomes obvious in the topmost $2.5 \mathrm{~m}$ of the profile. In the centre of the profile, a small part of max. resistivity (up to $100 \Omega \mathrm{m}$ ) occurs close to the surface.

Profile E7 (length: $45 \mathrm{~m}$, max. depth of penetration: circa $9 \mathrm{~m}$ b.s.) was performed north of profile E8 in an area where the former wall was undetected by MG. It presents similar results as E8. The uppermost $1.5 \mathrm{~m}$ reveal resistivity of $>50 \Omega \mathrm{m}$ and a max. of circa $100 \Omega \mathrm{m}$ at its eastern limit close to the surface. Below $1.5 \mathrm{~m}$ b.s. low resistivity of $<50 \Omega \mathrm{m}$ occurs. 


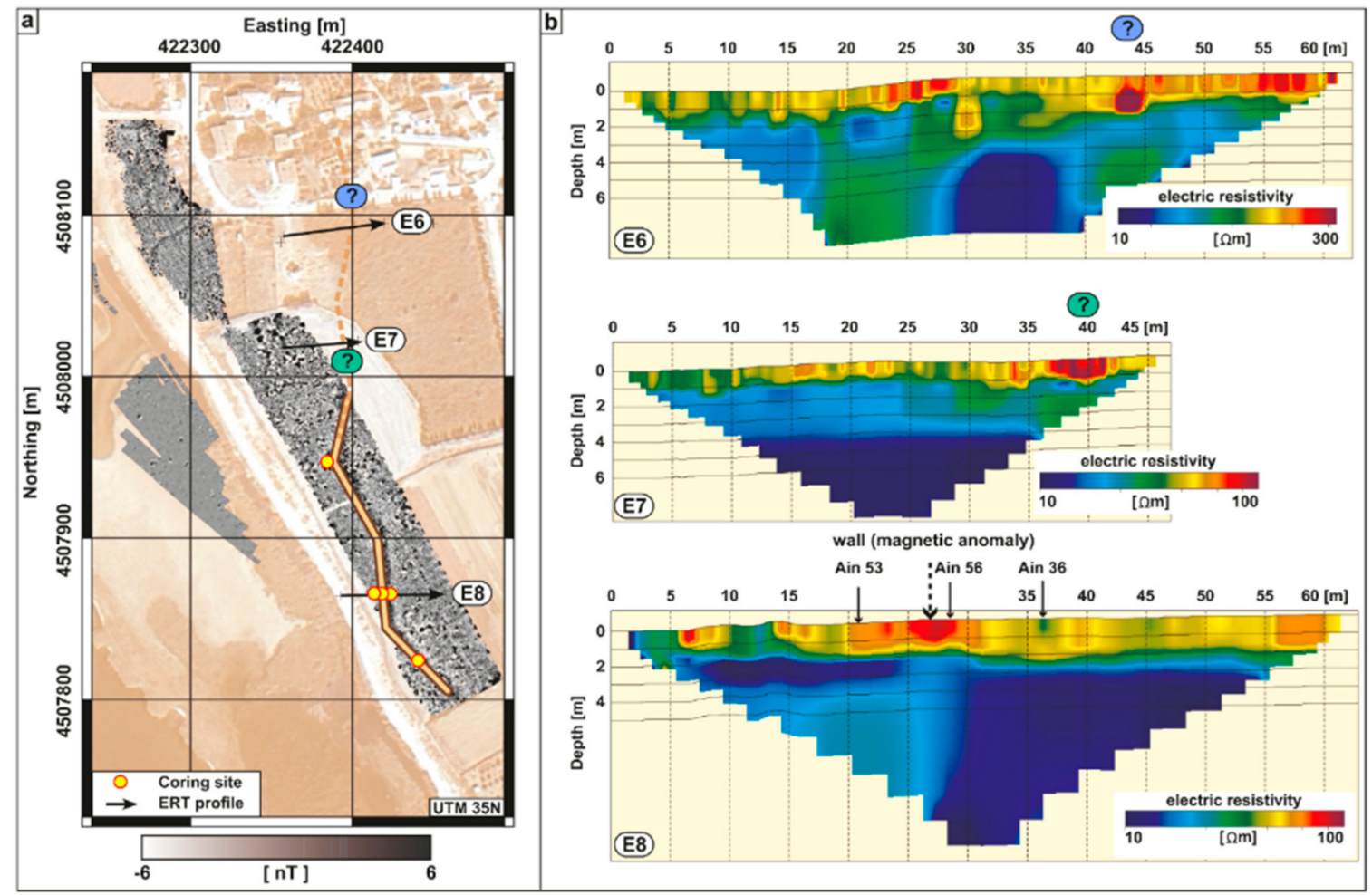

Figure 4. ERT transects in the area of the buried city wall. Wenner \& Schlumberger electrode arrangement, electrode spacing $1.0 \mathrm{~m}$. (a) Positions of the three ERT profiles E6-E8 shown on the map of the MG results. Profiles E6 and E7 were conducted in an area where no MG measurement had been carried out; (b) Simplified inverse model section of ERT profiles E6-E8. The high resistivity values in the area of the ? in E6 and E7 may be best interpreted as remains of the buried wall, which was then confirmed by coring Ain 56 in profile E8.

In comparison, profile E6 (length: $60 \mathrm{~m}$; max. depth of penetration: circa $9 \mathrm{~m}$ b.s.) presents slightly different results. The calculated range of electrical resistivity shows a variation of around $300 \Omega \mathrm{m}$, which is three times higher compared to E7 and E8. The profile is subdivided into two parts at a depth of circa $2 \mathrm{~m}$ b.s. The upper $2 \mathrm{~m}$ present several spots of high resistivity (above $150 \Omega \mathrm{m}$ ) while the part below $2 \mathrm{~m}$ b.s. shows low values of $<150 \Omega \mathrm{m}$.

\subsection{Results of the Coring Ain 53}

To investigate the style and the vertical thickness of the assumed city wall, altogether five corings were performed in the area around (Figures 3 and 5). As all corings are situated in a quite small area and show similar results, exemplarily, coring Ain 53 is presented in detail. Additionally, as a synopsis of the corings, the transect Ain 53 (forefront of the wall)-Ain 56 (inside the wall)-Ain 36 (inside the former city area) which crosses the supposed city wall orthogonally and situated on ERT profile 8 is discussed in Section 5. 


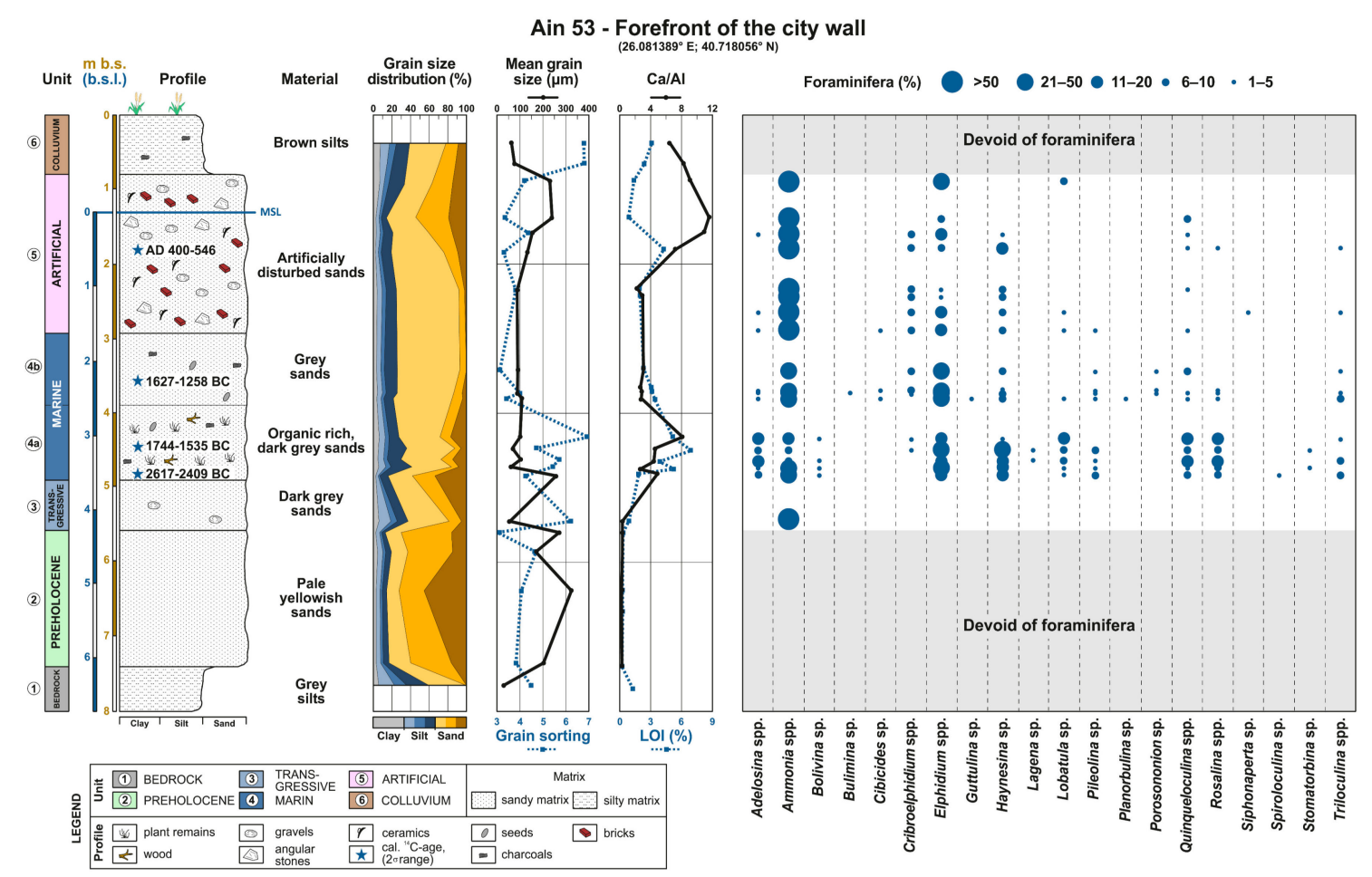

Figure 5. Sediment core Ain 53 (for location see Figures 3 and 4) with geochemical, sedimentological and foraminiferal parameters, supplemented by the interpretation of the depositional units and the dating results.

Ain $53\left(26.081389^{\circ} \mathrm{E} ; 40.718056^{\circ} \mathrm{N}\right.$; final depth: $8.00 \mathrm{~m}$ b.s. (elevation: $1.31 \mathrm{~m}$ a.s.l.; Figure 5) is situated in the forefront of the city wall, $8 \mathrm{~m}$ west of Ain 56. As it is presumably the least altered profile of the entire transect (Figure 6), Ain 53 was selected as case example. Based on foraminiferal associations and sedimentological results, the profile is divided into six units (Figure 5).

The lowermost unit 1-weathered limestone-was reached at $7.42 \mathrm{~m}$ b.s. $(6.11 \mathrm{~m}$ b.s.l.). The overlaying unit2 extends up to $5.58 \mathrm{~m}$ b.s. ( $4.27 \mathrm{~m}$ b.s.l.) and consists of pale yellowish, quite well-sorted sand (mean: 168-324 $\mu \mathrm{m}$ ). The sediment contains almost no organic remains and the $\mathrm{Ca} / \mathrm{Al}$ ratio is the lowest of the entire profile. Consequently, unit 2 is free of foraminifera tests. Oxidation spots are visible especially between 5.80 and $6.00 \mathrm{~m}$ b.s. (4.49-4.69 m b.s.l.).

Unit 2 is topped by a thin unit which is made of dark grey, poorly sorted sterile sands (unit 3) that reaches up to $4.90 \mathrm{~m}$ b.s. (3.59 $\mathrm{m}$ b.s.l.) and shows an increase in $\mathrm{LOI}$ and the $\mathrm{Ca} / \mathrm{Al}$ ratio. The range of foraminifera is very narrow, consisting of Ammonia spp. only.

The following unit 4 extends to $2.93 \mathrm{~m}$ b.s. (1.62 m b.s.1.) and is subdivided at $3.90 \mathrm{~m} \mathrm{b.s.}$ ( $2.59 \mathrm{~m}$ b.s.l.) in a lower unit $4 \mathrm{a}$ and an upper unit $4 \mathrm{~b}$. The entire unit 4 consists of fine dark grey sand (mean: $91-103 \mu \mathrm{m})$. Unit $4 \mathrm{a}$ is rich in macro-remains (seagrass, charcoal, and different seeds) as well as debris of marine molluscs. This is clearly reflected by the highest LOI of the entire profile $(5-7 \%)$ and rising $\mathrm{Ca} / \mathrm{Al}$ values. This part is rich in foraminifera, dominated by Elphidium spp., Haynesina sp., Quinqueloculina spp., and Rosalina spp. Two terrestrial plant remains date unit 4 a to 2617-2409 cal BC (Ain 53/480 at $4.80 \mathrm{~m}$ b.s., $3.49 \mathrm{~m}$ b.s.l.) and 1744-1535 cal BC (Ain 53/445 at $4.45 \mathrm{~m}$ b.s., $3.14 \mathrm{~m}$ b.s.l.) (Table 1). Unit $4 \mathrm{~b}$ shows similar characteristics as unit $4 \mathrm{a}$, but is of lighter colour and remarkably reduced in the number of macro-remains. This led to decreased LOI values. The foraminifera association is still mainly represented by Elphidium spp. and Haynesina sp., added by Ammonia spp., while Quinqueloculina spp. and Rosalina spp. occur less frequently compared to unit 4a. This unit is dated by a marine snail fragment at $3.65 \mathrm{~m}$ b.s. (2.34 $\mathrm{m}$ b.s.l.) to $1627-1258 \mathrm{cal} \mathrm{BC}$ (Ain 53/365; Table 1). 


\section{City-wall transect}

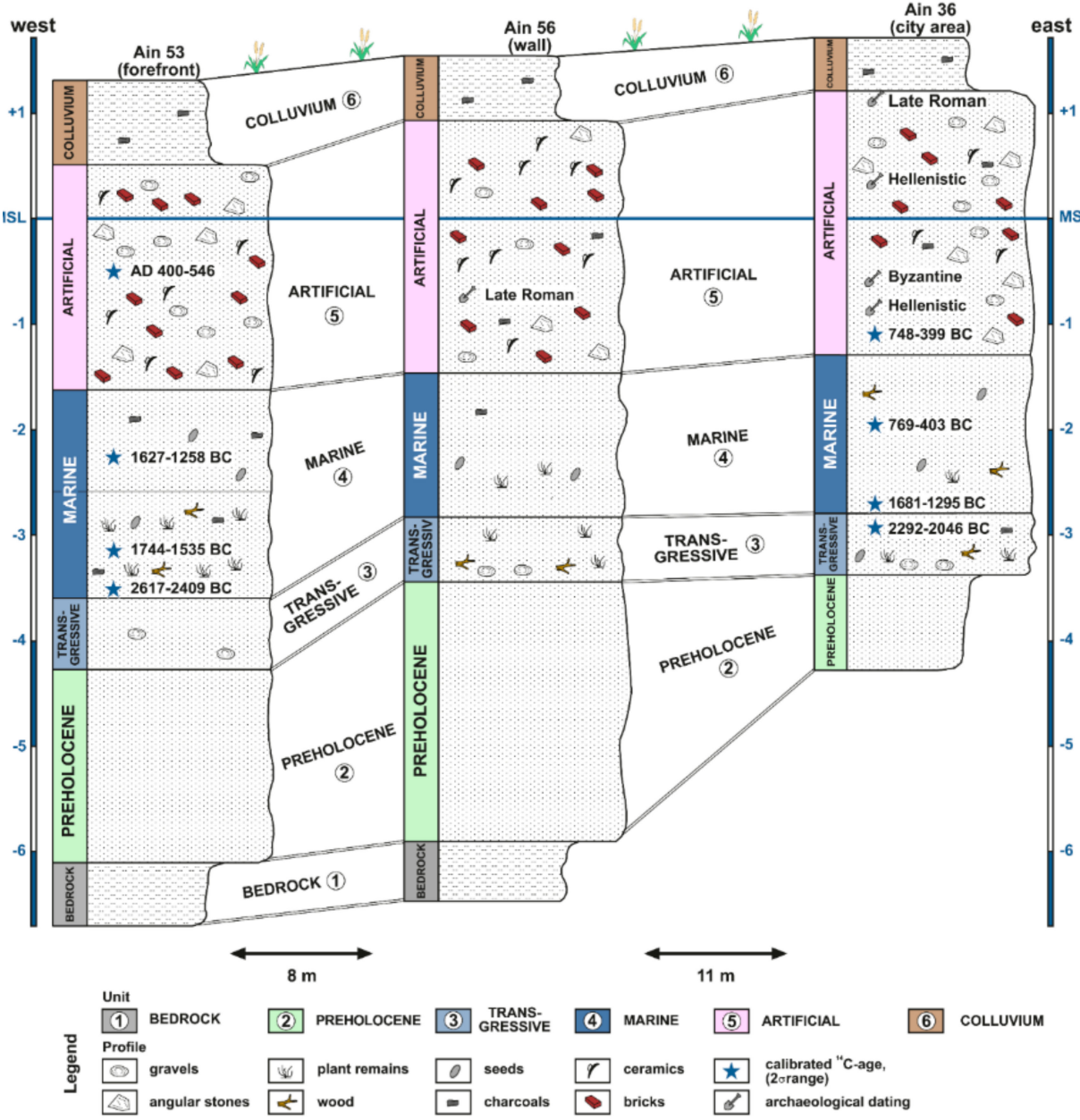

Figure 6. Synopsis of the coring transect Ain 53-56-36 situated directly on the track of the ERT profile E8 (for location see Figure 4).

Table 1. Radiocarbon data sheet. ${ }^{14} \mathrm{C}$-AMS dating was carried out at the ${ }^{14}$ Chrono Centre for Climate, the Environment, and Chronology, Queen's University Belfast, UK (lab code: UBA). All ages were calibrated with IntCal13 or MARINE13 using the Calib 7.1 software [62]. A marine reservoir effect of $390 \pm 85$ years and a $\Delta \mathrm{R}$ of $35 \pm 70$ years were applied [63]. The calibrated ages are presented in calendar years BC/AD and years BP (before AD 1950) with $2 \sigma$ confidence interval.

\begin{tabular}{|c|c|c|c|c|c|}
\hline Depth b.s. (m) & $\begin{array}{l}\text { Depth b.s.l. } \\
\text { (m)/a.s.1. (m) }\end{array}$ & $\mathrm{d}^{13} \mathrm{C}(\%)$ & Libby-Age & $\begin{array}{l}\text { Calibrated }{ }^{14} \text { C Ages } \\
\text { Cal BC/Cal AD }(2 \sigma)\end{array}$ & $\begin{array}{c}\text { Calibrated }{ }^{14} \mathrm{C} \text { Ages } \\
\text { Cal BP }(2 \sigma)\end{array}$ \\
\hline 1.65 & 0.14 a.s.l. & -22.8 & $1610 \pm 24$ & AD 395-536 & 1414-1555 ВР \\
\hline 3.64 & 1.85 b.s.l. & -23.3 & $2424 \pm 28$ & 747-404 BC & 2353-2696 BP \\
\hline 4.85 & 3.06 b.s.l. & -12.1 & $3847 \pm 33$ & 2457-2205 BC & 4154-4406 ВР \\
\hline 6.75 & 4.96 b.s.l. & -9.6 & $3893 \pm 30$ & 2468-2293 BC & $4242-4417$ BP \\
\hline 2.80 & 1.08 b.s.l. & -25.6 & $2413 \pm 35$ & 748-399 BC & 2348-2697 BP \\
\hline 3.66 & 1.94 b.s.l. & 0.2 & $2847 \pm 22$ & $769-403$ ВС & 2352-2718 ВР \\
\hline 4.42 & 2.70 b.s.l. & -15.8 & $3585 \pm 33$ & 1681-1295 ВC & 3244-3630 BР \\
\hline 4.62 & 2.90 b.s.l. & -11.4 & $3779 \pm 33$ & 2292-2046 BC & 3995-4241 BР \\
\hline 1.80 & 0.49 b.s.l. & -22.3 & $1588 \pm 34$ & AD 400-546 & 1404-1550 ВР \\
\hline 3.65 & 2.34 b.s.l. & 3.2 & $3547 \pm 24$ & $1627-1258$ ВС & 3207-3576 ВР \\
\hline 4.45 & 3.14 b.s.l. & -10.7 & $3364 \pm 34$ & 1744-1535 ВС & 3484-3693 ВР \\
\hline 4.80 & 3.49 b.s.l. & -11.6 & $3988 \pm 34$ & 2617-2409 BC & $4358-4566$ ВР \\
\hline 3.65 & 1.98 b.s.l. & 3.1 & $3102 \pm 33$ & 1097-755 BC & 2704-3046 BP \\
\hline 4.57 & 2.90 b.s.l. & -16.6 & $2779 \pm 32$ & $1004-842$ BC & 2791-2953 BР \\
\hline 4.70 & 3.03 b.s.l. & -15.0 & $2985 \pm 26$ & 1285-1120 BC & 3069-3234 ВР \\
\hline 5.30 & 3.63 b.s.l. & -17.3 & $3651 \pm 28$ & 2134-1941 ВC & 3890-4083 ВР \\
\hline
\end{tabular}


Unit 5 includes a mixed layer defined by a shift at $2.93 \mathrm{~m}$ b.s. (1.62 $\mathrm{m}$ b.s.l.) and is characterised by well-rounded pebbles, angular split-face stones, and human debris (undatable pieces of bricks and broken pottery). The foraminiferal assemblage is similar to the one in unit 4, especially in the lower part of unit 5, but overall less diverse and dominated by Ammonia spp. and Elphidium spp. A charcoal fragment at $1.80 \mathrm{~m}$ b.s. ( $0.49 \mathrm{~m}$ b.s.l.) dates this unit to AD 400-546 (Ain 53/180; Table 1).

The topmost unit 6 between $0.80 \mathrm{~m}$ b.s. (0.51 $\mathrm{m}$ a.s.l.) and the surface consists of poorly sorted, fine-grained brown silts (mean 63-76 $\mu \mathrm{m}$ ) with small pieces of bricks, angular stones, and plant remains. Moreover, unit 6 does not contain foraminifera and the uppermost $0.32 \mathrm{~m}$ are marked by farming activities (plough horizon).

\section{Discussion}

\subsection{Palaeogeographical Evolution of the Area}

The general palaeogeographical evolution of the area is exemplified by coring profile Ain 53 in combination with the coring transect Ain 53-56-36 (Figures 5 and 6).

\subsubsection{Interpretation of Coring Ain 53}

The bedrock (Neogene limestone) is outcropping at some hillside places of the castle hill and was used as building material through time in Ainos. Consequently, it was hit at the base of coring Ain 53 (Figure 5) at $7.42 \mathrm{~m}$ b.s. (6.11 m b.s.l.; unit 1).

The reduced $\mathrm{Ca} / \mathrm{Al}$ ratio, the very low $\mathrm{LOI}$, the grain-size parameters and the lack of foraminifera of the overlying unit 2 hint to a riverine origin - most probably deposited during pre-Holocene times.

This is topped by the transgressive littoral unit 3 which represents the onset of the Holocene sea-level rise at this site. The high-energy environment is obvious from several pebbles, the coarse grain size, the poor sorting, rising LOI, and higher $\mathrm{Ca} / \mathrm{Al}$ ratios. The low biodiversity and the sole occurrence of robust foraminifera, such as Ammonia spp., in the lower part of unit 3 indicate the high stress level of this littoral environment in which not many species are able to survive. Following the age distribution (Ain 53/480; Figure 5), the Holocene transgression reached this area long before the main human occupation period of Ainos in the 1st millennium BC. Furthermore, steadily rising sea level led to the formation of a shallow-water body represented by unit 4 . The greater water depth of unit $4 \mathrm{~b}$ compared to unit $4 \mathrm{a}$ caused by the inland migration of the shoreline led to reduced wave action at the coring site. This results in a lower amount of shell and snail debris and reduced $\mathrm{Ca} / \mathrm{Al}$ ratios. The foraminifera assemblage indicates a shallow marine water body since the themed- $3^{\text {rd }}$ millennium BC (Ain 53/480; 2617-2409 cal BC) that remained at this spot for more than 1000 years, until the people of Ainos dumped the artificial unit 5 to turn the area into dry land. The onset of the human impact is not precisely datable by radiocarbon directly. Creating a Sequence in Oxcal followed by an interpolation of the desired depth is useless because of the unknowingness of (1) the correctness of the radiocarbon ages gained out of the artificial unit 5 (Ain 53/180; Table 1), and (2) the possible removing of sediment of unit $4 \mathrm{~b}$ during the construction process of the wall and its foundation in the forefront. OSL-dating of the sediment immediately below the artificial foundation of unit $5[22,23]$ failed due to the impracticality of coring through the massive unit 5 . An attempt to decipher the onset of the human impact and hence the construction of the wall will be presented in Section 5.2. As the foundation was put in a former marine environment, the quite diverse foraminifera spectrum is not surprising but should not be overestimated.

Since the area of coring site Ain 53 suddenly became terrestrial, the second transition of the shoreline, often indicated by a regressive littoral unit, is missing. The artificial unit 5 shows a slight transition to the uppermost unit 6 that characterises the plough horizon of an already harvested barley field (Figure 3a). 


\subsubsection{Synopsis of the Landscape Evolution}

After the detailed interpretation of one representative sediment core, a spatial transect is discussed to clarify the construction history of the wall in this area (Figure 6).

Due to their proximity, the three cores show similar results. The pre-Holocene-most probably fluvial-unit 2 is topped by the transgressive unit 3 that is of similar thickness in all cores. Due to difficulties while coring through the massive unit 5 , unit 3 is positioned circa $0.5 \mathrm{~m}$ lower in Ain 53 compared to Ain 56 and Ain 36. Consequently, the marine transgression hit the shores roughly during the first half of the 3rd millenium BC. The establishment of a shallow-marine water body (unit 4) becomes visible in all cores at a similar depth; it can roughly be stated for the beginning of the 2nd millennium BC. Based on Ain 36, the marine influence continued at least until Archaic to Classical times (Ain 36/366F; Table 1; Figure 6). Important in the context of this paper is the transition depth between units 4 and 5 which marks the onset of the human impact: it occurs between $1.62 \mathrm{~m}$ (Ain 53) and $1.29 \mathrm{~m}$ b.s.l. (Ain 36); above this depth, the human impact is clearly evident (Figure 6). This is additionally backed by the results of Ain 58, cored directly in the MG anomaly of Tower A. Ain 58 is very similar to Ain 53, showing the typical profile with all of the six units. Here, the transition between units 4 and 5 is at a depth of $1.63 \mathrm{~m}$ b.s.l.

\subsection{The Age of the City Wall}

As already stated above, we cannot date the transition of units 4 and 5 , representing the beginning of the human impact and the construction of the wall with geoscientific means directly. Nevertheless, based on the ${ }^{14} \mathrm{C}$-ages of unit 4 , diagnostic ceramics and building criteria we can state an age for the construction of the wall (Figure 7).

Firstly, the radiocarbon ages of cores Ain 35, 36, 53 and 58 do not present ages of unit 4 younger than 747-404 cal BC (Ain 35/364) and 769-403 cal BC (Ain36/366F), respectively, which suggests to date the onset of human activity as later than Archaic to Classical times. Secondly, unit 5 of corings Ain 36 and 56 contains only datable ceramics of Hellenistic and younger ages. This acts as a "terminus post quem", and dates the onset of human activity to the Hellenistic era or later. Thirdly, there are arguments from building criteria and archaeological sources. Comparable zig-zag-line city walls are known from other cities in Asia Minor (e.g., Iasos, Pergamum, and Priene), the Greek mainland (e.g., Samikon and Stratos) and Syria (e.g., Dura Europos). They date to the 4th century BC, and particularly to Hellenistic times. A prominent example can be found at Samothrace-an island situated immediately southwest of Ainos-where a part of the city wall was built as indented trace in early Hellenistic times [65-67].

This construction style is the result of the development of enhanced siege techniques during Hellenistic times, especially the advanced artillery, which is described by Philo of Byzantium [66] in the late 3rd/early 2 nd century BC. The advantage of this type of fortification is obvious: A besieger was forced to concentrate on the projecting tower before it was possible to face the wall. In turn, directly attacking the wall would have caused crossfire by the towers. Summing up, we can state that the city wall in this area was most probably erected in Hellenistic times. Massive construction works - not only of the area in the forefront of the city - were undertaken by the inhabitants of those days. Unfortunately, it is not possible to differentiate the material of unit 5 in "wall-material" and "substruction-material". 


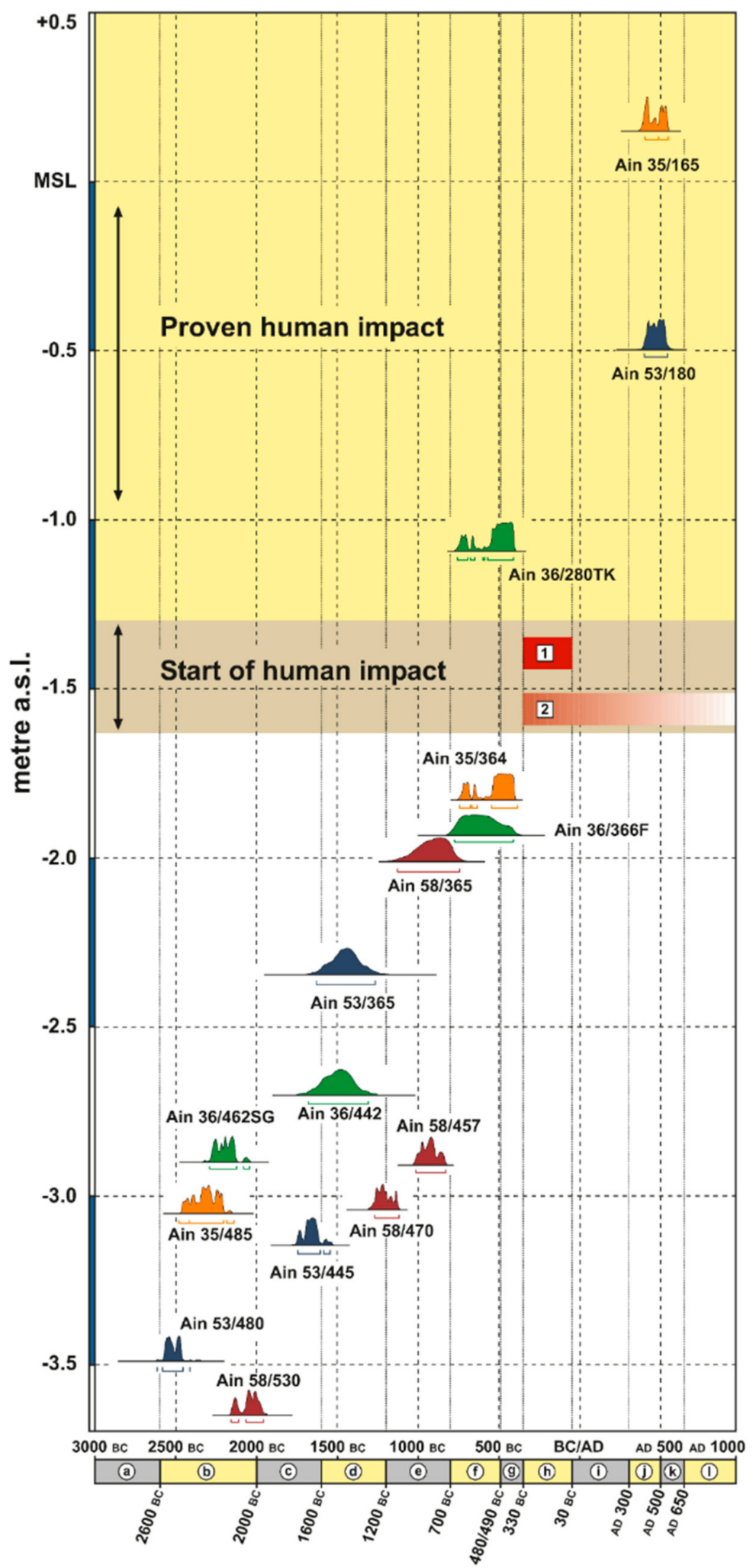

Figure 7. Synopsis of radiocarbon ages of corings Ain 35, 36, 53, and 58 (Table 1). Additionally, the zone of the cores where the human impact is about to start and where it is proven are marked. Historic periods: (a) Neolithic; (b) Early Minoan; (c) Middle Minoan; (d) Late Minoan; (e) Dark Ages; (f) Archaic; (g) Classical; (h) Hellenistic; (i) Roman Imperial; (j) Late Antiquity; (k) Early Byzantine; (1) Middle Byzantine. Human Impact: (1) Construction style of the wall dates it to Hellenistic times; (2) No traces of human impact of Classical age or older have been found in the cores. 


\subsection{Detection of the Possible Extension of the Wall Course Using ERT}

As MG results are lacking in the northern part of the research area (Figure 3), the further course of the wall remains unclear so far. Nevertheless, it can be assumed that it continues northwards, still performing the zig-zag style. Based on the results of coring Ain 56, the thickness of unit 5 (anthropogenic material) is about $3 \mathrm{~m}$ which is more or less backed by the results of ERT profile $\mathrm{E} 8$, where the upmost section showing a spot of highest resistivity is just $1.5 \mathrm{~m}$ thick. The reduced thickness of the ERT anomaly compared to the coring might be explained by the groundwater level, which is situated at circa the same depth. Due to the short distance of about $30 \mathrm{~m}$ to the brackish water of the lagoon, the groundwater is probably also influenced by the brackish water, the salt content of which causes lower resistivities. Similar spots of high resistivity are also found in ERT profiles E6 and E7, which can be best interpreted as traces of the former wall. Extending the known segment of the wall with exactly the same building structures northwards fits well to the hypothetic wall course deduced from the geophysical data.

\section{Conclusions}

During Hellenistic times, Ainos was fortified by a massive city wall equipped with several towers. For that purpose, the inhabitants were forced to consolidate the near-coastal swampy area south of the city to make it a robust ground for erecting this immense building. By applying a multi-proxy approach based on the analyses of geophysical, sedimentological, microfaunistical, and historical data, we are able to describe the environmental conditions into which this wall was placed in. Moreover, we detect the further extension of the wall to less investigated areas and determine a "terminus post quem" for the construction age of the wall dating it to Hellenistic times. The final proof of the wall's age can only be determined by an archaeological excavation. Summing up, our multi-proxy approach acts as a valuable example for investigating buried structures in archaeological contexts where an excavation is too expensive, time consuming, or even forbidden.

Author Contributions: M.S., E.E., P.F., T.S., and A.P. designed this study. E.E., D.W., and T.W. generated the geophysical data and conducted the geophysical measurements. H.B. (Heike Bücherl), M.H., and M.S. performed the geoarchaeological fieldwork mainly containing coring, sampling, and levelling the coring locations by DGPS. The laboratory analyses were carried out by M.H., N.S., and P.W. in the laboratories in Cologne and Jena, both in Germany. The overall project administration was in the hands of S.B. (during field work in Turkey) and M.S. (during the rest of the year). The first draft of the manuscript was written by M.S. and improved by E.E., T.S., D.W., and T.W., while all figures were done by E.E., M.S., and D.W. Th.S. interpreted the literary and archaeological sources. Funding for this research was acquired by H.B. (Helmut Brückner), W.R., and T.S.

Funding: Financial support was granted by the German Research Foundation (DFG ref. nos. BR 877/31/1-2, SCHM 2831/1-2 and RA496/26-1).

Acknowledgments: This project was conducted in the context of the DFG priority program (SPP) 1630 "Harbours-from the Roman Period to the Middle Ages" (2012-2018). Further information dealing with this six-year project can be found in the cited paper (www.schloss-gottorf.de/zbsa/publikationen/jahresberichte/ jahresbericht-2011/jahresbericht-2011/files / zbsa_jahresbericht_2011_teil_1.pdf). Our research was part of the greater Ainos Project, headed by the excavation director Prof Dr Sait Başaran, (İstanbul Üniversitesi, Turkey). We thank his entire team working in the excavation house in Ainos for the generous support during our fieldwork for several years. We are grateful to Prof Dr Beate Böhlendorf-Arslan (Philipps-University Marburg, Germany) for determining the ceramic finds in cores Ain 36 and 53. The Ministry of Culture and Tourism of the Republic of Turkey kindly granted the research permits. Helpful comments from two anonymous reviewers are gratefully acknowledged.

Conflicts of Interest: The authors declare no conflict of interest.

\section{References}

1. Al-Sibahy, A.; Edwards, R. Characterization of the clay masonry units and construction technique at the ancient city of Nippur. Eng. Struct. 2017, 147, 517-529. [CrossRef]

2. Frederiksen, R. Greek City Walls of the Archaic Period, 900-480 BC; Oxford University Press: Oxford, UK, 2011; pp. 1-320. 
3. Leontarakis, K.; Apostolopoulos, G.V. Model Stacking (MOST) technique applied in cross-hole ERT field data for the detection of Thessaloniki ancient walls' depth. J. Appl. Geophys. 2013, 93, 101-113. [CrossRef]

4. Müth, S.; Ruppe, U. Regional begrenzte Phänomene. In Ancient Fortifications: A Compendium of Theory and Practice; Müth, S., Schneider, P., Schnelle, M., De Staebler, P., Eds.; Oxbow Books: Oxford, UK, 2016; pp. 231-248.

5. Kraft, J.C.; Aschenbrenner, S.E.; Rapp, G., Jr. Paleogeographic reconstructions of coastal Aegean archeological sites. Science 1977, 195, 941-947. [CrossRef] [PubMed]

6. Kraft, J.C.; Brückner, H.; Kayan, İ.; Engelmann, H. The geographies of ancient Ephesus and the Artemision in Anatolia. Geoarchaeology 2007, 22, 121-149. [CrossRef]

7. Goodman, B.N.; Reinhardt, E.; Dey, H.; Boyce, J.; Schwarcz, H.; Sahoglu, V.; Erkanal, H.; Artzy, M. Evidence for Holocene marine transgression and shoreline progradation due to barrier development in Iskele, Bay of Izmir, Turkey. J. Coast. Res. 2008, 24, 1269-1280. [CrossRef]

8. Goodman, B.N.; Reinhardt, E.G.; Dey, H.W.; Boyce, J.I.; Schwarcz, H.P.; Sahoglu, V.; Erkanal, H.; Artzy, M. Multi-proxy geoarchaeological study redefines understanding of the paleocoastlines and ancient harbours of Liman Tepe (Iskele, Turkey). Terra Nova 2009, 21, 97-104. [CrossRef]

9. Marriner, N.; Morhange, C.; Kaniewski, D.; Carayon, N. Ancient harbour infrastructure in the Levant: tracking the birth and rise of new forms of anthropogenic pressure. Sci. Rep. 2014, 4, 5554. [CrossRef] [PubMed]

10. Delile, H.; Blichert-Toft, J.; Goiran, J.P.; Stock, F.; Arnaud-Godet, F.; Bravard, J.P.; Brückner, H.; Albarède, F. Demise of a harbor: A geochemical chronicle from Ephesus. J. Archaeol. Sci. 2015, 53, 202-213. [CrossRef]

11. Hadler, H.; Kissas, K.; Koster, B.; Mathes-Schmidt, M.; Mattern, T.; Ntageretzis, K.; Reicherter, K.; Willershäuser, T.; Vött, A. Multiple Late-Holocene tsunami landfall in the eastern Gulf of Corinth recorded in the palaeotsunami geoarchive at Lechaion, harbour of ancient Corinth (Peloponnese, Greece). Z. Geomorphol. 2013, 57, 139-180. [CrossRef]

12. Pint, A.; Seeliger, M.; Frenzel, P.; Feuser, S.; Erkul, E.; Berndt, C.; Klein, C.; Pirson, F.; Brückner, H. The environs of Elaia's ancient open harbour-A reconstruction based on microfaunal evidence. J. Archaeol. Sci. 2015, 54, 340-355. [CrossRef]

13. Morhange, C.; Giaime, M.; Marriner, N.; abu Hamid, A.; Bruneton, H.; Honnorat, A.; Kaniewski, D.; Magni, F.; Porotov, A.V.; Wante, J.; Zviely, D.; Artzy, M. Geoarchaeological evolution of Tel Akko's ancient harbour (Israel). J. Archaeol. Sci. Rep. 2016, 7, 71-81. [CrossRef]

14. Salel, T.; Bruneton, H.; Lefèvre, D. Ostracods and environmental variability in lagoons and deltas along the north-western Mediterranean coast (Gulf of Lions, France and Ebro delta, Spain). Rev. Micropaléontol. 2016, 59, 425-444. [CrossRef]

15. Evelpidou, N.; Karkani, A.; Kampolis, I.; Pirazzoli, P. Late Holocene shorelines in east Attica (Greece). Quat. Int. 2017, 436, 1-7. [CrossRef]

16. Flaux, C.; Marriner, N.; el-Assal, M.; Kaniewski, D.; Morhange, C. Late Holocene erosion of the Canopic promontory (Nile Delta, Egypt). Mar. Geol. 2017, 385, 56-67. [CrossRef]

17. Giaime, M.; Morhange, C.; Ontiveros, M.A.C.; Fornós, J.J.; Vacchi, M.; Marriner, N. In search of Pollentia's southern harbour: Geoarchaeological evidence from the Bay of Alcúdia (Mallorca, Spain). Palaeogeogr. Palaeoclim. Palaeoecol. 2017, 466, 184-201. [CrossRef]

18. Pennington, B.T.; Sturt, F.; Wilson, P.; Rowland, J.; Brown, A.G. The fluvial evolution of the Holocene Nile Delta. Quat. Sci. Rev. 2017, 170, 212-231. [CrossRef]

19. Finkler, C.; Baika, K.; Rigakou, D.; Metallinou, G.; Fischer, P.; Hadler, H.; Emde, K.; Vött, A. Geoarchaeological investigations of a prominent quay wall in ancient Corcyra-Implications for harbour development, palaeoenvironmental changes and tectonic geomorphology of Corfu Island (Ionian Islands, Greece). Quat. Int. 2018, 473, 91-111. [CrossRef]

20. Karkani, A.; Evelpidou, N.; Giaime, M.; Marriner, N.; Maroukian, H.; Morhange, C. Late Holocene palaeogeographical evolution of Paroikia Bay (Paros Island, Greece). Comptes Rendus Geosci. 2018, 350, 202-211. [CrossRef]

21. Melis, R.T.; Di Rita, F.; French, C.; Marriner, N.; Montis, F.; Serreli, G.; Sulas, F.; Vacchi, M. 8000 years of coastal changes on a western Mediterranean island: A multiproxy approach from the Posada plain of Sardinia. Mar. Geol. 2018, 403, 93-108. [CrossRef] 
22. Seeliger, M.; Brill, D.; Feuser, S.; Bartz, M.; Erkul, E.; Kelterbaum, D.; Vött, A.; Klein, C.; Pirson, F.; Brückner, H. The Purpose and Age of Underwater Walls in the Bay of Elaia of Western Turkey: A Multidisciplinary Approach. Gearchaeology 2014, 29, 138-155. [CrossRef]

23. Klasen, N.; Engel, M.; Brückner, H.; Hausleiter, A.; Intilia, A.; Eichmann, R.; al-Najem, M.; al-Said, S. Optically stimulated luminescence dating of the city wall system of ancient Tayma (NW Saudi Arabia). J. Archaeol. Sci. 2011, 38, 1818-1826. [CrossRef]

24. Alpar, B. Plio-Quaternary history of the Turkish coastal zone of the Enez-Evros Delta: NE Aegean Sea. Mediterr. Mar. Sci. 2001, 2, 95-118. [CrossRef]

25. Anthony, E.J.; Marriner, N.; Morhange, C. Human influence and the changing geomorphology of Mediterranean deltas and coasts over the last 6000 years: From progradation to destruction phase? Earth-Sci. Rev. 2014, 139, 336-361. [CrossRef]

26. Başaran, S. The excavations at Enez (Ainos). In İstanbul University's Contributions to Archaeology in Turkey 1932-2000; Belli, O., Ed.; İstanbul Üniversitesi: İstanbul, Turkey, 2001; pp. 219-226.

27. Başaran, S. Enez (Ainos); İstanbul Üniversitesi: İstanbul, Turkey, 2010; pp. 1-132.

28. Anzidei, M.; Antonioli, F.; Benini, A.; Lambeck, K.; Sivan, D.; Serpelloni, E.; Stocchi, P. Sea level change and vertical land movements since the last two millennia along the coasts of south-western Turkey and Israel. Quat. Int. 2011, 232, 13-20. [CrossRef]

29. Flemming, N.C. Holocene eustatic changes and coastal tectonics in the Northeast Mediterranean: Implications for models of crustal consumption. Philos. Trans. R. Soc. Lond. Math. Phys. Sci. 1978, 289, 405-458. [CrossRef]

30. Seeliger, M.; Bartz, M.; Erkul, E.; Feuser, S.; Kelterbaum, D.; Klein, C.; Pirson, F.; Vött, A.; Brückner, H. Taken from the sea, reclaimed by the sea: The fate of the closed harbour of Elaia, the maritime satellite city of Pergamum (Turkey). Quat. Int. 2013, 312, 70-83. [CrossRef]

31. Seeliger, M.; Pint, A.; Frenzel, P.; Feuser, S.; Pirson, F.; Riedesel, S.; Brückner, H. Foraminifera as markers of Holocene sea-level fluctuations and water depths of ancient harbours-A case study from the Bay of Elaia (W Turkey). Palaeogeogr. Palaeoclim. Palaeoecol. 2017, 482, 17-29. [CrossRef]

32. Alpar, B.; Erel, J.; Gazioglu, C.; Gokasan, E.; Adatepe, F.; Demirel, S.; Algan, O. Plio-Quaternary evolution of the Enez Delta, NE Aegean Sea. Turk. J. Mar. Sci. 1998, 4, 11-28.

33. Homer. Iliad; Translated by Hampe, R., Ed.; Reclam: Leipzig, Saxony, Germany, 1986; pp. 1-622, (Greek to German).

34. Başaran, S. Die Ausgrabungen in Ainos (Ein Überblick). In Thrace in the Graeco-Roman World, Proceedings of the 10th International Congress of Thracology, Komotini, Greece, 18-23 October 2005; Institute for Greek and Roman Antiquity, National Hellenic Research Foundation: Athens, Greece, 2007; pp. 72-79.

35. Karadima, C. Ainos: An Unknown Amphora Production Centre in the Evros Delta. In Transport Amphorae and Trade in the Eastern Mediterranean, Proceedings of the International Colloquium, Athens, Greece, 26-29 September 2002; Eiring, J., Lund, J., Eds.; Monographs of the Danish Institute: Athens, Greece, 2004; pp. 155-161.

36. Kaygusuz, I. Erzen: A stempel auf amphorenhenkeln aus Ainos (Enez). Epigr. Anatolica 1986, 7, 7-16.

37. May, J.M.F. Ainos: Its History and Coinage, 474-341 B.C.; University Press: London, UK, 1950; pp. 1-288.

38. Strack, M.L. Die antiken Münzen von Dacien und Moesien. In Die antiken Münzen Nord-Griechenlands; Druck und verla von Georg Reimer: Berlin, Germany, 1898; p. 69.

39. Casson, S. Macedonia, Thrace, and Illyria: Their Relations to Greece from the Earliest Times Down to the Time of Philip, Son of Amyntas; Oxford University Press: Oxford, UK, 1926; pp. 1-21.

40. Isaac, B.H. The Greek Settlements in Thrace until the Macedonian Conquest; Brill: Leiden, The Netherlands, 1986; pp. 1-306.

41. Lätzer-Lasar, A. Das römische Handelsnetz von Ainos: Ausgewählte Keramik vom Späthellenismus bis zur Spätantike. Rei Cretariae Romanae Fautorum Acta 2016, 44, 707-714.

42. Soustal, P. Thrakien (Thrake, Rodope, Haimimontos); Austrian Academy of Sciences: Vienna, Austria, 1991; pp. 1-580.

43. Procopius. On Buildings; Translated by Dewing, H.B., Downey, G., Eds.; Harvard University Press: Cambridge, MA, USA, 1949; pp. 1-561, (Greek to English).

44. Avreamea, A. Land and Sea Communications, Fourth-Fifteenth Centuries. In Economic History of Byzantium: From the Seventh through the Fifteenth Century; Laiou, A., Ed.; Dumbarton Oaks: Washington, DC, USA, 2002; pp. 57-90. 
45. Matschke, K.P. Commerce, Trade, Markets, and Money, Thirteenth—Fifteenth Centuries. In Economic History of Byzantium: From the Seventh through the Fifteenth Century; Laiou, A., Ed.; Dumbarton Oaks: Washington, DC, USA, 2002; pp. 771-806.

46. Makris, G. Ships. In Economic History of Byzantium: From the Seventh through the Fifteenth Century; Laiou, A., Ed.; Dumbarton Oaks: Washington, DC, USA, 2002; pp. 91-100.

47. Qusterhout, R. The Byzantine Church at Enez. Problems in Twelfth-Century Architecture. Jahrb. Österr. Byzantistik 1985, 35, 261-280.

48. Ousterhout, R.; Bakirtzis, Ch. The Byzantine Monuments of the Evros/Meriç River Valley; European Center for Byzantine and Post-Byzantine Monuments: Thessaloniki, Greece, 2007; pp. 1-184.

49. Loke, M.H.; Barker, R.D. Least-squares deconvolution of apparent resistivity pseudo-sections. Geophysics 1995, 60, 1682-1690. [CrossRef]

50. Engel, M.; Knipping, M.; Brückner, H.; Kiderlen, M.; Kraft, J.C. Reconstructing middle to late Holocene palaeogeographies of the lower Messenian plain (southwestern Peloponnese, Greece): Coastline migration, vegetation history and sea level change. Paleogeogr. Paleoclim. Paleoecol. 2009, 284, 257-270. [CrossRef]

51. Ernst, W. Geochemical Facies Analysis; Elsevier: Amsterdam, The Netherlands, 1970; pp. 1-158.

52. Folk, R.L.; Ward, W.C. Brazos River bar: A study in the significance of grain size parameters. J. Sediment. Petrol. 1957, 27, 3-26. [CrossRef]

53. Blott, S.J.; Pye, K. GRADISTAT: a grain size distribution and statistics package for the analysis of unconsolidated sediments. Earth Surf. Process. Landf. 2001, 26, 1237-1248. [CrossRef]

54. Mook, D.H.; Hoskin, C.M. Organic determinations by ignition: Caution advised. Estuar. Coast. Shelf Sci. 1982, 15, 697-699. [CrossRef]

55. Heiri, O.; Lotter, A.F.; Lemcke, G. Loss on ignition as a method for estimating organic and carbonate content in sediments: reproducibility and comparability of results. J. Paleolimnol. 2001, 25, 101-110. [CrossRef]

56. Dankers, N.; Laane, R. A comparison of wet oxidation and loss on ignition of organic material in suspended matter. Environ. Technol. Lett. 1983, 834, 283-290. [CrossRef]

57. Salehi, M.H.; Hashemi, B.O.; Bigi, H.H.; Esfandiarpour, B.I.; Motaghian, H.R. Refining soil organic matter determination by loss-on-ignition. Pedosphere 2011, 21, 473-482. [CrossRef]

58. Vött, A.; Bareth, G.; Brückner, H.; Lang, F.; Sakellariou, D.; Hadler, H.; Ntageretzis, K.; Willershäuser, T. Olympia's harbour site Pheia (Elis, Western Peloponnese, Greece) destroyed by tsunami impact. Die Erde 2011, 142, 259-288.

59. Lubos, C.; Dreibrodt, S.; Bahr, A. Analysing spatio-temporal patterns of archaeological soils and sediments by comparing pXRF and different ICP-OES extraction methods. J. Archaeol. Sci. Rep. 2016, 9, 44-53. [CrossRef]

60. Cimerman, F.; Langer, M.R. Mediterranean foraminifera. Slovenska Akademija Znanosti in Umetnosti; Academia Scientarium et Artium Slovenca: Ljubliana, Slovenia, 1991; pp. 1-118.

61. Meriç, E.; Avsar, N.; Bergin, F. Benthic foraminifera of eastern Aegean Sea (Turkey); systematics and autoecology. Turkish Mar. Res. Found. 2004, 18, 1-306.

62. Reimer, P.J.; Bard, E.; Bayliss, A.; Beck, J.W.; Blackwell, P.G.; Bronk Ramsey, C.; Buck, C.E.; Cheng, H.; Edwards, R.L.; Friedrich, M.; et al. IntCal13 and MARINE13 radiocarbon age calibration curves 0-50000 years calBP. Radiocarbon 2013, 55, 1869-1887. [CrossRef]

63. Siani, G.; Paterne, M.; Arnold, M.; Bard, E.; Metivier, B.; Tisnerat, N.; Bassinot, F. Radiocarbon reservoir ages in the Mediterranean Sea and Black Sea. Radiocarbon 2000, 42, 271-280. [CrossRef]

64. Ramsey, C.B. Deposition models for chronological records. Quat. Sci. Rev. 2008, 27, 42-60. [CrossRef]

65. Lehmann, K. Samothrace: A Guide to the Excavations and the Museum. Institute of Fine Art; New York University: Thessaloniki, Greece, 1998; pp. 1-184.

66. Winter, F.E. The Indented Trace in Later Greek Fortifications. Am. J. Archaeol. 1971, 75, 413-426. [CrossRef]

67. Winter, F.E. Greek Fortifications; Routledge \& Kegan Paul: London, UK, 1971; pp. 1-388.

(C) 2018 by the authors. Licensee MDPI, Basel, Switzerland. This article is an open access article distributed under the terms and conditions of the Creative Commons Attribution (CC BY) license (http://creativecommons.org/licenses/by/4.0/). 